\title{
ANALISIS PERHITUNGAN METODE PENYUSUTAN AKTIVA TETAP MENURUT PSAK NO.16 DAN UNDANG-UNDANG PERPAJAKAN SERTA PENGARUHNYA TERHADAP LAPORAN KEUANGAN PT KALANAFAT PUTRA
}

\author{
Markus Muda, SE \\ Program Studi Diploma IV Akuntansi \\ Politeknik Katolik Saint Paul Sorong \\ Email: markusmuda@gmail.com
}

\begin{abstract}
ABSTRAK
Perbedaan Perhitungan Biaya Penyusutan Menurut Standar Akuntansi Keuangan dan Undang-Undang Perpajakan di sebut juga dengan beda waktu. Perbedaan waktu tersebut dikarenakan adanya perbedaan dalam menghitung biaya penyusutan. Perbedaan tersebut berpengaruh terhadap besarnya Laba Penghasilan Kena Pajak. Tujuan penelitian adalah memberikan gambaran perbedaan antara Perhitungan metode Penyusutan Menurut PSAK No.16 dan Perpajakan. Adanya Perbedaan pengakuan beban penyusutan akan mengakibatkan terjadinya koreksi fiskal tujuan dilakukannya koreksi adalah untuk mengoreksi beban yang telah diakui komersial dan fiskal, sehingga terlihat selisih yang mengakibatkan adanya pengurangan biaya yang telah diakui dalam laporan laba rugi komersial.
\end{abstract}

Kata Kunci : Aktiva, Penyusutan, PSAK, UU Perpajakan, Komersial, Fiskal.

\begin{abstract}
Differences in Depreciation Cost Calculations According to Financial Accounting Standards and Taxation Law are also called time differences. The time difference is due to the difference in calculating depreciation cost. These differences affect the amount of taxable income. The purpose of this study is to provide a description of the difference between the Calculation of Depreciation method according to PSAK No.16 and Taxation. The difference in recognition of depreciation expense will result in a fiscal correction of the purpose of correction is to correct the expense recognized commercially and fiscally, so that the difference exists resulting in the reduction of costs recognized in the commercial income statement.
\end{abstract}

Keywords: Assets, Depreciation, PSAK, Taxation Law, Commercial, Fiscal

\section{PENDAhuluan}

\section{Latar Belakang}

Perusahaan Konstruksi ialah suatu kegiatan membangun sarana maupun prasarana, perusahaan ini merupakan salah satu usaha dalam sektor ekonomi yang melaksanakan pertencanaan, pelaksanaan, dan pengawasan.. Kegiatan konstruksi ini membentuk suatu bangunan atau bentuk fisik lain yang dalam pelaksanaan, penggunaan dan pemanfaatan bangunan tersebut menyangkut kepentingan dan keselamatan masyarakat pengguna bangunan tersebut. Secara umum tujuan utama di dirikannya sebuah perusahaan ini untuk memperoleh laba yang optimal atas investasi yang telah ditanamkan dan dapat mempertahankan kelancaran perusahaan dalam jangka waktu yang panjang. Salah satu investasi tersebut adalah aktiva yang mempunyai umur masa manfaat lebih dari satu tahun. Untuk mencapainya diperlukan pengelolaan yang efektif dalam penggunan, pemeliharaan maupun pencatatan akuntansinya.

Setiap perusahaan memiliki aktiva tetap karena aktiva tetap merupakan sarana bagi perusahaan di dalam menjalankan kegiatan operasional, seperti gedung, kantor, kendaraan sebagai alat untuk fasilitas perusahaan dan lainlain sebagai alat yang dapat mendukung semua kegiatan Perusahaan. Mengenai aktiva tetap tidak lepas dari kebijakan metode penyusutan 
dari aktiva tetap itu sendiri, Metode penyusutan yang akan di pakai tergantung dari kebijakan yang akan di tetapkan oleh perusahaan. Perusahaan harus mempertimbangkan metode yang akan di gunakan oleh perusahaan dalam menghitung penyusutan aktiva tetap. Perusahaan harus mempertimbangkan untung ruginya untuk masa yang akan datang dalam penentuan metode penyusutan aktiva tetap. Oleh karena itu beban penyusutan harus di alokasikan sesuai dengan Standar Akuntansi Keuangan yang berlaku umum.

Ada perbedaan ketentuan yang mengatur perhitungan penyusutan aktiva tetap yaitu ketentuan menurut Pernyataan standar akuntansi keuangan (PSAK) No.16 dengan ketentuan Peraturan Perundang-undangan Perpajakan No.36 Tahun 2008 Tentang pajak penghasilan, perbedaan tersebut antara lain metode penyusutan, tarif penyusutan, dan masa manfaat/umur ekonomis suatu aktiva tetap perbedaan tersebut disebut dengan beda waktu.

Beda waktu yang di sebabkan oleh adanya perbedaan penyusutan menurut perpajakan No.36 tahun 2008 dan PSAK No.16 yang akan berpengaruh terhadap besarnya laba kena pajak sebagai akibat dari perbedaan ini perusahaan melakukan koreksi fiskal Positif di lihat dari hasil perbandingan perhitungan penyusutan aktiva tetap menurut PSAK No.16 dan Undangundang Perpajakan. Dari latar belakang masalah di atas maka penulis mengangkat judul "Analisis Perhitungan Metode Penyusutan Aktiva Tetap Menurut Psak No. 16 Dan Undang-Undang Perpajakan Serta Pengaruhnya Terhadap Laporan Keuangan PT. Kalanafat Putra"

\section{Batasan Masalah}

Penelitian ini membatasi ruang lingkup permasalahan yang hanya membahas pengaruh beda waktu yang disebabkan oleh perbedaan metode penyusutan menurut PSAK No 16 dan Undang-Undang perpajakan terhadap laporan keuangan.

\section{Tujuan Penelitian}

Tujuan dilakukannya penelitian ini untuk mengetahui perbandingan biaya pada laporan keuangan PT. Kalanafat Putra akibat adanya beda waktu karena perbedaan metode penyusutan antara Pernyataan Standar Akuntansi Keuangan (PSAK) No.16 dan Undang-undang Perpajakan No.36 Tahun 2008.

\section{TINJAUAN PUSTAKA Pengertian Aktiva Tetap}

Aktiva tetap adalah aktiva yang: (1) jangka waktu pemakaiannya lama; (2) digunakan dalam kegiatan perusahaan; (3) dimiliki tidak untuk dijual kembali dalam kegiatan normal perusahaan serta; (4) nilainya cukup besar. Aktiva ini dapat di golongkan menjadi aktiva tetap berwujud (tangible fixed assets) dan aktiva tak berwujud (intangible assets). tidak ada kriteria standar mengenai jangka waktu pemakaian minimal untuk membedakan aktiva tetap dengan aktiva lainnya. Walaupun demikian, pemakaian lebih dari satu tahun, pada umumnya, digunakan sebagai pedoman. Kriteria lain adalah aktiva tersebut harus dipakai dalam kegiatan perusahaan dan tidak untuk dijual kembali.

Berdasarkan pernyataan Standar Akuntansi Keuangan (PSAK) N0.16 butir 5 Aktiva tetap adalah aktiva berwujud yang di peroleh dalam bentuk siap pakai atau dengan di bangun lebih dahulu, yang digunakan dalam operasi perusahaan, tidak di maksudkan untuk dijual dalam rangka kegiatan normal perusahaan dan mempunyai masa manfaat lebih dari satu tahun.

\section{Harga perolehan Aset Tetap}

Harga perolehan aset tetap meliputi semua jumlah yang di keluarkan untuk mendapatkan aset tetap dan membuatnya siap di gunakan. sebagai contoh, biaya pengangkutan dan pemasangan peralatan termasuk sebagai bagian dari total biaya aset tetap. Biaya langsung yang berkaitan dengan konstruksi baru, seperti buruh dan bahan baku, didebit sebagai akun aset "pekerjaan dalam penyelesaian" (construction in progress). Ketika konstruksi selesai, biaya penyusutan fungsional terjadi jika aset tetap yang di maksud tidak lagi mampu menyediakan manfaat dengan tingkat seperti di harapkan.

\section{Faktor-faktor dalam perhitungan Depresiasi/penyusutan}

Ada tiga faktor yang berpengaruh dalam perhitungan depresiasi/penyusutan, yaitu:

a. Biaya perolehan.

b. Masa manfaat. 
c. Nilai residu.

Undang-Undang Nomor 36 Tahun 2008 Tentang pajak penghasilan pada pasal 11

Peraturan Menteri Keuangan Republic Indonesia Nomor 96/PMK.03/2009

\section{Pengertian Akuntansi Penyusutan}

Semua jenis aktiva tetap, kecuali tanah, akan makin berkurang kemampuannya untuk memberikan jasa bersamaan dengan berlalunya waktu. Beberapa faktor yang mempengaruhi menurunnya kemampuan ini adalah pemakaian, ketidak seimbangan kapasitas yang tersedia dengan yang di minta dan keterbelakangan tekonologi.berkurangnnya kapasitas berarti kurangnnya nilai aktiva tetap yang bersangkutan. Hal ini perlu dicatat dan dilaporkan. Pengakuan adanya penurunan nilai aktiva tetap berwujud di sebut penyusutan.

Menurut Jusup Haryono dalam bukunya Dasar-dasar Akuntansi menyatakan bahwa "Penyusutan adalah proes pengalokasian harga perolehan aktiva tetap menjadi biaya selama masa manfaatnya dengan cara yang rasional dan sistematis

\section{Klasifikasi Akuntansi Pajak}

Ketentuan Perpajakan kan mengelompokan aktiva tetap kepada aktiva yang dapat di susut (depreciable asset; misalnya, bangunan, mesin, dan peralatan, yang lain). Untuk tujuan penyusutan, ketentuan perpajakan mengelompokan aktiva menjadi bangunan dan bukan bangunan (kelompok masa manfaat 1, 2, 3, dan 4). Aktiva kelompok 1 merupakan aktiva yang mempunyai manfaat tidak lebih dari 4 tahun, kelompok 2 mempunyai masa manfaat 8 tahun, kelompok 3 mempunyai masa manfaat 16 tahun, dan kelompok 4 mempunyai masa manfaat 20 tahun
Perolehan Aktiva Tetap menurut Perpajakan

Aktiva tetap dapat di peroleh dengan berbagai cara, seperti melalui pembelian (tunai, kredit, atau angsuran), capital lease, pertuk, pertukaran (sekuritas atau aktiva yang lain), sebagai penyertaan modal, pembangunan sendiri, hibah atau pemberian, dan penyerahan karena selesainya masa kontrak bangun-gunaserah (built-operate and transfer)

\section{Penyusutan dan Amortisasi menurut Undang-Undang Perpajakan}

Berbeda dengan kebiasaan akuntansi komersial yang mengenal deplesi (alokasi sistematis dan rasional biaya perolehan sumber alam), ketentuan perpajakan tidak mengenal istilah itu. Berdasarkan ketentuan pasal 33 UUD 1945, kekayaan sumber alam dikuasai oleh negara dan pihak swasta tidak di perkenankan untuk memiliki sumber alam sehingga ketentuan pajak tidak mengenal deplesi. Alokasi sistematis dan rasional atas hak pemanfaatan sumber alam diperkenankan dalam bentuk amortisasi (alokasi sistematis dan rasional harga perolehan hak atau intangible assets). Amortisasi demikian pada hakikatnya setara dengan deplesi.

\section{Penyusutan Harta Berwujud menurut Undang-Undang Perpajakan}

Penyusutan dilakukan atas pengeluaran untuk pembelian, pendirian, penambahan, perbaikan, atau perubahan harta berwujud, kecuali tanah yang bersatatus hak milik, hak guna bangunan, hak guna usaha, dan hak pakai, yang di miliki dan digunakan untuk mendapatkan, menagih, dan memelihara penghasilan yang mempunyai masa manfaat lebih dari 1 (satu) tahun. Untuk dapat melakukan penyusutan dan amortisasi maka terlebih dahulu harus di ketahui : (1) harta perolehan atau cost dari harta berwujud yang harus disusut, dan (2) tarif penyusutan. 
Tabel 2.3

Rumus Tarif penyusutan perpajakan

\begin{tabular}{|l|c|c|c|}
\hline $\begin{array}{c}\text { Kelompok Harta } \\
\text { Berwujud }\end{array}$ & $\begin{array}{c}\text { Masa } \\
\text { Manfaat }\end{array}$ & $\begin{array}{c}\text { Tarif Garis } \\
\text { Lurus }\end{array}$ & $\begin{array}{c}\text { Tarif Saldo } \\
\text { Menurun (\%) }\end{array}$ \\
\hline Bukan bangunan : & & & 50 \\
\hline Kelompok 1 & 4 & 25 & 25 \\
\hline Kelompok 2 & 8 & 12.5 & 12.5 \\
\hline Kelompok 3 & 16 & 6.25 & 10 \\
\hline Kelompok 4 & 20 & 5 & - \\
\hline Bangunan : & & & - \\
\hline a. Permanen & 20 & 5 & \\
\hline b. Permanen & 10 & 10 & \\
\hline
\end{tabular}

\section{Sumber : S. Munaawir}

\section{Laporan Keuangan}

Setelah transaksi dicatat dan diikhtisarkan, maka disiapkan laporan bagi pemakai. Laporan akuntansi yang menghasilkan informasi demikian disebut laporan keuangan. Laporan keuangan yang utama bagi perusahaan perseorangan adalah laporan laba rugi, laporan ekuitas pemilik, neraca, dan laporan arus kas. Urut-urutan penyusutan dan sifat data yang terdapat dalam laporan-laporan tersebut adalah sebagai berikut :

a. Laporan laba rugi - ikhtisar pendapatan dan beban selama periode waktu tertentu, misalnya sebulan atau setahun.

b. Laporan ekuitas pemilik - ikhtisar perubahan ekuitas pemilik yang terjadi selama periode waktu tertentu, misalnya sebulan atau setahun.

c. Neraca - daftar aset, kewajiban, dan ekuitas pemilik pada pada tanggal tertentu, biasanya pada akhir bulan atau akhir tahun.

d. Laporan arus kas - ikhtisar penerimaan kas dan pembayaran kas selama periode waktu tertentu, misalnya sebulan atau setahun.

\section{METODE PENELITIAN}

Jenis Penelitian Penelitian ini berupa data laporan keuangan dalam bentuk tabel berupa laporan laba rugi dan neraca yang ada di perusahaan PT. Kalanafat, dimana perhitungan metode penyusutan yang di gunakan perusahaan konstruksi ini menggunakan metode garis lurus dan saldo menurun dan di koreksi fikal antara perhitungan komersial dan fiskal atas perbandingan perhitungan metode penyusutan menurut Pernyataan Standar Akuntansi Keuangan No 16 dan menurut Peraturan UU Perpajakan.

\section{Populasi}

Populasi yang akan diteliti dalam penelitian ini adalah Aktiva tetap Perusahaan menurut PSAK No 16 dan Undang-undang Perpajakan pada PT.Kalanafat putra dalam melakukan aktivitas atau kegiatan sehari-hari perusahaan.

\section{Teknik Pengambilan Sampel}

Sampel pada penelitian ini dibatasi pada elemen-elemen yang dapat memberikan informasi yang berkaitan dengan penyusutan aktiva tetap pada perusahaan PT.Kalanafat Putra. Untuk membuat perbandingan perhitungan penyusutan aktiva tetap menurut PSAK No.16 dan Perhitungan Menurut Undangundang Perpajakan.

\section{Jenis dan sumber data}

Jenis data

a. Data Kuantitatif

b. Data kualitatif.

\section{Sumber Data}

Sumber data yang digunakan untuk menunjang penelitian ini adalah data primer dan data sekunder :

a. Data primer

b. Data sekunder 


\section{Metode pengumpulan data}

a. Wawancara, tanya jawab langsung dengan pihak perusahaan khususnya pada bagian accounting mengenai penerapan metode perhitungan penyusutan yang digunakan.

b. Dokumentasi yaitu merupakan metode pengumpulan data berasal dari dokumen atau arsip perusahaan yang mencakup

\section{Teknik analisis}

Teknik analisis data yang digunakan dalam penelitian ini adalah sebagai berikut:

a. Mengumpulkan informasi yang berhubungan dengan judul skripsi

b. Memperoleh gambaran umum dari objek penelitian secara keseluruhan serta mengetahui permasalahan yang ada

c. Mengumpulkan data dari objek penelitian

d. Mengolah data yang diperoleh, dengan contoh kasus perhitungan sebagai berikut:

\section{PEMBAHASAN.}

\section{Penyajian Data PT. Kalanafat Putra}

Berdasarkan data yang diperoleh, Data tersebut merupakan data utama dari penelitian ini yang berupa laporan keuangan, daftar aktiva tetap, serta surat-surat perusahaan yang menyangkut tentang gambaran Umum PT.Kalanafat Putra antara lain ialah surat pernyataan badan usaha, surat izin usaha jasa konstruksi nasional, tanda daftar perusahaan, dan surat izin usaha perdagangan (SIUP), peranan surat-surat dalam perusahaan di maksudkan untuk dapat menyajikan gambaran umum perusahaan berdasarkan data dari perusahaan PT.Kalanafat Putra.

PT. Kalanafat Putra merupakan salah satu perusahaan yang memiliki asset tetap dalam jumlah besar, Karena bergerak di bidang jasa Konstruksi yang merupakan jasa kontraktor dan levenransir, penting bagi perusahaan ini untuk mengelola dan melakukan prosedur Akuntansi menurut PSAK, oleh karena itu akan menjadi suatu masalah jika asset tetap tidak dikelola dan dilakukakan prosedur akuntansi yang sesuai PSAK, apalagi mengingat seluruh kegiatan operasional yang menghasilkan pendapatan bagi PT. Kalanafat Putra berasal dari penggunaan Aset Tetap.

Adapun Data yang di peroleh dari PT. Kalanafat Putra adalah Laporan Keuangan berupa Laporan Neraca dan Laporan Laba Rugi serta daftar aktiva tetap perusahaan. Adapun data tersebut sebagai berikut : 
Tabel 4.1

Laporan Neraca PT. Kalanafat Putra

\begin{tabular}{|c|c|c|c|c|c|}
\hline \multicolumn{6}{|c|}{$\begin{array}{c}\text { PT. KALANAFAT PUTRA } \\
\text { NERACA } \\
\text { PER } 31 \text { DESEMBER } 2015\end{array}$} \\
\hline \multirow[t]{2}{*}{ NO } & \multicolumn{2}{|l|}{ AKTIVA } & \multirow[t]{2}{*}{ NO } & \multicolumn{2}{|r|}{ PASSIVA } \\
\hline & KETERANGAN & Rp. & & KETERANGAN & \\
\hline 1 & А КTIVA I ANCA & & $A$ & HUTANG IANCAR & \\
\hline 11 & Kas dan Setara Kas & 5122835042 & 4 & Hutang Paisk & \\
\hline & $\begin{array}{l}\text { (Bank) } \\
\text { Piutano Kontrak }\end{array}$ & 0.122 .835 .942 & & & \\
\hline 1.2 & $\begin{array}{l}\text { Proyek } \\
\text { Prong Kon }\end{array}$ & - & 4.2 & Hutang Usaha & \\
\hline 1.3 & Piutang Lain-lain & - & 4.3 & Hutang Bank & \\
\hline 1.4 & Biaya dibayar dimuka & - & 4.4 & Pekerjaan dalam Proses & \\
\hline 1.5 & Persedian Bahan & - & & & \\
\hline \multicolumn{2}{|c|}{ Jumlah Aktiva Lancar } & 5.122 .835 .942 & \multicolumn{2}{|c|}{ Jumlah Hutang Lancar } & \\
\hline 2 & \multicolumn{2}{|l|}{ AKTIVA TETAP } & 5 & \multicolumn{2}{|l|}{ HUTANG JANGKA PANJANG } \\
\hline 2.1 & Tanah & 342.580 .000 & & \multirow{3}{*}{ Jumlah Hutang Jangka Panjang } & - \\
\hline 2.2 & \multirow{3}{*}{$\begin{array}{l}\text { Bangunan } \\
\text { Peralatan Berat dan } \\
\text { Mesin } \\
\text { Kendaraan }\end{array}$} & 452.000 .000 & & & \\
\hline 2.3 & & 20.003.259.746 & & & \\
\hline 2.4 & & 4.002 .000 .000 & 6 & MODAL SAHAM & \\
\hline \multirow[t]{2}{*}{2.5} & \multirow{2}{*}{$\begin{array}{r}\text { Inventaris Kantor } \\
\text { Jumlah Harga } \\
\text { Perolehan }\end{array}$} & 100.000 .000 & 6.1 & Modal Disetor & 250.000 .000 \\
\hline & & 24.899 .839 .746 & 6.2 & Laba (Rugi) Tahun Lalu & 6.599 .406 .185 \\
\hline 2.6 & Akumulasi Penyusutan & $\begin{array}{l}-\quad 12.726 .477 .925 \\
\end{array}$ & 6.3 & Laba (Rugi) Tahun Berjalan & $\underline{10.446 .791 .578}$ \\
\hline \multicolumn{2}{|c|}{ Jumlah Aktiva Tetap } & 12.173.361.820 & \multicolumn{2}{|c|}{ Jumlah Modal Saham } & 17.296.197.763 \\
\hline \multicolumn{3}{|c|}{$\begin{array}{l}\text { AKTIVA LAINNYA } \\
\text { Jumlah Aktiva Lainnya }\end{array}$} & & & \\
\hline & TOTAL AKTIVA & 17.296.197.762 & & TOTAL PASSIVA & 17.296.197.762 \\
\hline
\end{tabular}

\section{Sumber : PT. Kalanafat Putra}

Dari Laporan Neraca tersebut, Aktiva tetap merupakan, aktiva yang nilainya tinggi yaitu sebesar Rp. 24.899.839.746.- berdasarkan data ini lah penulis akan membuat perbandingan beda waktu yang disebabkan oleh perbedaan metode penyusutan menurut PSAK dan Undang-undang perpajakan terhadap laporan keuangan. 
Tabel 4.3

Daftar Aktiva Tetap Komersial PT.Kalanafat Putra

\begin{tabular}{|c|c|}
\hline \multicolumn{2}{|l|}{$\begin{array}{c}\text { PT. KALANAFAT PUTRA } \\
\text { LABA / (RUGI) } \\
\text { PER } 31 \text { DESEMBER } 2015\end{array}$} \\
\hline KETERANGAN & KONSTRUKSI \\
\hline $\begin{array}{l}\text { I. PENDAPATAN } \\
\text {-Pendapatan Pekerjaan Proyek } \\
\text { Jumlah Pendapatan } \\
\text { II. HARGA POKOK PENJUALAN } \\
\text { Biaya Pelaksanaan Proyek } \\
\text {-Bahan Baku/ Material } \\
\text { - Biaya Operasional Alat, Spart Part, BBM \& Oil } \\
\text { - Mobilisasi \& Demobilisasi Kendaraan \& Alat Berat } \\
\text { - Upah Langsung } \\
\text { Jumlah Harga Pokok Penjualan } \\
\text { III. LABA KOTOR USAHA }\end{array}$ & $\begin{array}{r}70.569 .868 .000 \\
7.340 .361 .000 \\
1.142 .575 .000 \\
3.081 .650 .000 \\
82.134 .454 .000 \\
17.193 .833 .273\end{array}$ \\
\hline $\begin{array}{l}\text { IV. BIAYA USAHA LAINNYA (UMUM \& ADMINISTRASI) } \\
\text { - Gaji Karyawan } \\
\text { - Transport Lokal } \\
\text { - Biaya Penyusutan } \\
\text { Sub Jumlah } \\
\text { - Biaya ATK } \\
\text { - Telepon/ HP, Koran, Listrik, dan Air } \\
\text { - Konsumsi Karyawan } \\
\text { - Perlengkapan Kantor } \\
\text { - Biaya Dokumen Lelah/ Kontrak dan Pelaporan } \\
\text { - Reparasi \& Pemeliharaab Kendaraan dan Peralatan } \\
\text { - Perjalanan Dinas \& Akomodasi } \\
\text { - Perpanjangan \& Kelengkapan Surat Perusahaan } \\
\text { - Asuransi Tenaga Kerja } \\
\text { - Asuransi Administrasi Bank } \\
\text { - Biaya Lain-lain } \\
\text { Sub Jumlah } \\
\text { Jumlah Biaya Usaha Lainnya (Umum \& Administrasi) } \\
\text { V. LABA / (RUGI) SEBELUM PAJAK }\end{array}$ & $\begin{array}{r}922.750 .000 \\
67.225 .000 \\
3.206 .171 .849 \\
4.196 .146 .849 \\
27.371 .500 \\
69.420 .000 \\
343.200 .000 \\
19.000 .000 \\
25.115 .000 \\
297.603 .000 \\
120.840 .000 \\
81.500 .000 \\
1.291 .566 .000 \\
108.248 .000 \\
2.831 .346 \\
164.200 .000 \\
2.550 .894 .846 \\
6.747 .041 .695 \\
\end{array}$ \\
\hline & $\underline{10.446 .791 .578}$ \\
\hline
\end{tabular}

\section{Sumber : PT. Kalanafat Putra}

Metode penyusutan aktiva tetap yang digunakan oleh PT.Kalanafat Putra adalah metode penyusutan Garis Lurus untuk semua jenis aktiva tetap berupa bangunan, inventaris kantor, kendaraan, dan peralatan berat serta mesin. Penyusutan dengan menggunakan metode garis lurus besarnya penyusutan tiap-tiap tahunnya sama besar yaitu harga perolehan dikurangi nilai residu. Nilai sisa dibagi dengan masa manfaatnya jadi Beban Penyusutan Menurut Perusahaan Sebesar Rp. 3.206.171.849.-

\section{Hasil Analisis data}

Hasil analisis data atau Penelitian ini terfokus pada Laporan Keuangan PT. Kalanafat Putra yang pada dasarnya tentang perhitungan 
penyusutan Aset Perusahan PT.Kalanafat Putra dan meneliti perbedaan penyusutan aktiva tetap menurut Pernyataan Standard Akuntansi Keuangan (PSAK) dan menurut Undang-undang Perpajakan, berdasarkan dengan data laporan keuangan dan daftar penyusutan aktiva tetap yang berupa bangunan, inventaris kantor, kendaraan, dan peralatan berat serta mesin. Daftar aktiva tetap digunakan untuk menghitung besarnya penyusutan menurut pernyataan standar akuntansi keuangan (PSAK) dan menurut Undang-undang Perpajakan

Berdasarkan judul dan batasan masalah yang telah dirumuskan, maka berikut ini dilakukan analisis dari hasil penelitian mengenai Penyusutan Aktiva Tetap Menurut Pernyataan Standard akuntansi keuangan (PSAK) dan menurut Undang-undang Perpajakan, Penelitian yang dilakukan berdasarkan batasan-batasan masalah yang telah ditetapkan atau di rumuskan dalam bab I, yaitu penulis meneliti perbandingan hasil penyusutan yang mempengaruhi laporan keuangan yang disebabkan oleh perbedaan metode penyusutan menurut PSAK No.16 dan Undang-undang perpajakan No.36 Tahun 2008 dengan menganalisis pada data utama dari perusahaan PT.Kalanafat Putra berupa laporan keuangan.

\section{Analisis Perhitungan Penyusutan Menurut Pernyataan Standar Akuntansi Keuangan}

Data yang berupa aktiva tetap tersebut digunakan untuk menghitung penyusutan. Di mulai dengan menghitung penyusutan aktiva tetap menurut pernyataan standard akuntansi keuangan

Aktiva tetap akan mengalami penyusutan dari suatu periode ke periode berikutnya, jadi nilai kegunaan dari aktiva tetap akan terus berkurang dari suatu periode ke periode berikutnya, kecuali tanah. Dalam suatu periode tertentu apabila sudah digunakan atau dimanfaatkan maka nilai aktiva tetap akan mengalami penurunan. Aktiva tetap yang nilainya tidak akan berkurang, bahkan nilainya cenderung bertambah atau semakin tinggi adalah tanah. Seiring dengan bertambahnya waktu, nilai dari sebidang tanah akan mengalami penambahan atau semakin tinggi.

Penyusutan aktiva tetap terjadi karena berkurangnya nilai kegunaan dari aktiva tetap yang disebabkan karena adanya pemakaian aktiva tetap tersebut. Penyusutan dikenal juga dengan istilah depresiasi yaitu pengalokasian aktiva tetap yang disebabkan adanya penurunan nilai dari aktiva tetap tersebut.

Berdasarkan PSAK No 16, setiap bagian dari asset yang memiliki biaya perolehan cukup signifikan terhadap total biaya perolehan seluruh asset tetap disusutkan secara terpisah. Beberapa aturan tentang penyusutan diantaranya :

1. Beban penyusutan untuk setiap periode diakui dalam laba rugi, kecuali jika beban tersebut dimasukkan dalam jumlah tercatat asset lain

2. Jumlah tersusutkan dari suatu asset dialokasikan secara sistematis sepanjang umur manfaat

3. Nilai residu dan umur manfaat dari suatu asset dikaji setiap tahun

4. Jumlah tersusutkan suatu asset ditentukan setelah dikurangi nilai residunya.

5. Penyusutan suatu asset dimulai ketika asset siap digunakan.

6. Umur manfaat asset ditentukan berdasarkan perkiraan kegunaan suatu asset

7. Tanah dan bangunan merupakan asset yang dapat dipisahkan dan dicatat 
Tabel 4.4

Perhitungan Aktiva Tetap menurut Pernyataan Standar Akuntansi Keuangan

\begin{tabular}{|c|c|c|c|c|c|c|c|c|}
\hline \multicolumn{9}{|c|}{$\begin{array}{l}\text { Perhitungan Aktiva Tetap PT.Kalanafat Putra Menurut PSAK No.16 } \\
\text { Per } 31 \text { Desember } 2015\end{array}$} \\
\hline \multirow{2}{*}{\multicolumn{2}{|c|}{ Aset Perusahaan }} & \multirow{2}{*}{\multicolumn{2}{|c|}{$\begin{array}{l}\text { Bln/Thn } \\
\text { Perolehan }\end{array}$}} & \multirow{3}{*}{$\begin{array}{c}\begin{array}{c}\text { Harga } \\
\text { Perolehan }\end{array} \\
900.000 .000\end{array}$} & \multirow{3}{*}{$\begin{array}{c}\mathbf{b} \\
\begin{array}{c}\text { Nilai } \\
\text { Sisa }\end{array} \\
0 \\
\end{array}$} & \multirow{3}{*}{$\begin{array}{c}\begin{array}{c}\text { Masa } \\
\text { Manfaat }\end{array} \\
7\end{array}$} & \multirow{2}{*}{$\begin{array}{c}\text { d } \\
\text { Sisa Umur } \\
\text { Manfaat } \\
\text { s/d 1 January } \\
2017\end{array}$} & \multirow{2}{*}{$\begin{array}{c}=(\mathbf{a}-\mathbf{b}): \mathrm{c} \\
\begin{array}{c}\text { Beban } \\
\text { Penyusutan } \\
(\mathrm{Rp})\end{array}\end{array}$} \\
\hline & & & & & & & & \\
\hline 1 & Excavator Caterpilar 320 D & Mei & 2007 & & & & - & 0 \\
\hline 2 & Buldoser Caterpilar D6R & Mei & 2007 & 950.000 .000 & 0 & 8 & 1 & 118.750 .000 \\
\hline 3 & Dump Truck Dyna T.130HT & Agustus & 2007 & 422.200 .000 & 0 & 8 & 1 & 52.775 .000 \\
\hline 4 & Dump Truck Dyna T.130HT & February & 2008 & 226.100 .000 & 0 & 8 & 2 & 28.262 .500 \\
\hline 5 & Dump Truck Dyna $130 \mathrm{HT}$ & oktober & 2008 & 474.200 .000 & 0 & 8 & 2 & 59.275 .000 \\
\hline 6 & Excavator Caterpilar 320 D & Agustus & 2008 & 1.028 .272 .000 & 0 & 7 & 1 & 146.896 .000 \\
\hline 7 & Caterpilar Vibratory C5533E & Oktober & 2008 & 771.616 .000 & 0 & 8 & 2 & 96.452 .000 \\
\hline 8 & Excavator Caterpilar 320 D & Desember & 2008 & 1.223 .106 .745 & 0 & 8 & 2 & 152.888 .343 \\
\hline 9 & Dump Truck Dutro 130HD & January & 2009 & 249.500 .000 & 0 & 8 & 3 & 31.187 .500 \\
\hline 10 & Excavator Komatsu PC 200 & Agustus & 2009 & 1.102 .222 .000 & 0 & 8 & 3 & 137.777 .750 \\
\hline 11 & Buldoser K D85E-SS-2A/S1 & Agustus & 2009 & 1.903 .838 .000 & 0 & 8 & 3 & 237.979 .750 \\
\hline 12 & Excavator Komatsu PC 200 & Desember & 2009 & 800.000 .000 & 0 & 7 & 2 & 114.285 .714 \\
\hline 13 & Dump Truck Nissan 10 Roda & Desember & 2009 & 850.000 .000 & 0 & 7 & 2 & 121.428 .571 \\
\hline 14 & Dump Truck Hino 10 Roda & Desember & 2009 & 890.000 .000 & 0 & 8 & 3 & 111.250 .000 \\
\hline 15 & Lemari Arsip & January & 2010 & 10.500 .000 & 0 & 2 & - & 0 \\
\hline 16 & Kursi + Meja Kerja & January & 2010 & 9.500 .000 & 0 & 3 & - & 0 \\
\hline 17 & Laptop Toshiba L 510 & February & 2010 & 16.000 .000 & 0 & 4 & - & 0 \\
\hline 18 & Dump Truck H 1t0 R 260 JD & Juni & 2010 & 890.000 .000 & 0 & 8 & 3 & 111.250 .000 \\
\hline 19 & Air Conditioner (AC) & January & 2011 & 9.000 .000 & 0 & 8 & 4 & 1.125 .000 \\
\hline 20 & Mesin Foto Copy & January & 2012 & 28.000 .000 & 0 & 8 & 5 & 3.500 .000 \\
\hline 21 & Komputer + Printer \&Scan C & Maret & 2012 & 8.000 .000 & 0 & 4 & 1 & 2.000 .000 \\
\hline 22 & Alled Towing Winch & oktober & 2013 & 275.000 .000 & 0 & 8 & 6 & 34.375 .000 \\
\hline 23 & bangunan Non Permanen & January & 2014 & 452.000 .000 & 0 & 10 & 9 & 45.200 .000 \\
\hline 24 & Air Conditioner (AC) & January & 2014 & 19.000 .000 & 0 & 8 & 7 & 2.375 .000 \\
\hline 25 & Excavator PC $200 / \mathrm{C} 13015$ & April & 2014 & 1.436 .400 .000 & 0 & 8 & 7 & 179.550 .000 \\
\hline 26 & Buldozer D85E-SS-2/J16837 & Agustus & 2014 & 2.552 .805 .000 & 0 & 8 & 7 & 319.100 .625 \\
\hline 27 & Excavator Caterpilar 320D & November & 2014 & 1.400 .000 .000 & 0 & 7 & 6 & 200.000 .000 \\
\hline 28 & Excavator Caterpilar 320D & November & 2014 & 1.400 .000 .000 & 0 & 7 & 6 & 200.000 .000 \\
\hline 29 & Excavator Caterpilar 320D & November & 2014 & 1.400 .000 .000 & 0 & 7 & 6 & 200.000 .000 \\
\hline 30 & Ultratrex A H.U AT200 ER & Desember & 2014 & 2.860 .000 .000 & 0 & 8 & 7 & 357.500 .000 \\
\hline 31 & Tanah & January & 2014 & 342.580 .000 & 0 & - & - & - \\
\hline \multicolumn{4}{|c|}{ Total } & 24.899 .839 .745 & \multicolumn{3}{|c|}{ Total } & 3.065 .183 .754 \\
\hline
\end{tabular}

\section{Sumber : Data yang diolah}

Aset tetap yang dimiliki PT. Kalanafat Putra terdiri dari Bangunan, Peralatan berat/mesin, Kendaraan, dan Inventaris yang merupakan hak milik perusahaan tersebut. Perolehan aset tetap pada perusahaan PT.Kalanafat Putra dilakukan dengan perolehan asset dengan cara pembelian tunai, harga perolehan dihitung dengan cara memasukkan semua biaya yang bersangkutan dengan pembelian asset tersebut. Hal ini sesuai dengan aturan yang mereka pegang, dimana perusahaan menerapkan peraturan standar akuntansi keuangan No.16 mengenai klasifikasi asset tetap dan biaya selama masa perolehan asset tetap. 
Metode penyusutan yang digunakan perusahaan PT. Kalanafat Putra adalah metode garis lurus untuk semua asset perusahaan, jika kita bandingkan hasil dari penyusutan Aktiva tetap yang Perusahaan hitung dan yang Penulis Analisis terjadi perbandingan yang disebabkan oleh kurangnya ketelitian terhadap bagian
Accounting PT.Kalanafat Putra. Perhitungan Beban Penyusutan yang perusahaan hitung senilai $\mathrm{Rp}$ 3.206.171.849.- sedangkan yang penulis hitung senilai Rp. 3.065.183.754 dari nilai yang disajikan terjadi sellisih senilai $\mathrm{Rp}$. 140.988.095 selisih tersebut dikarenakan perusahaan masih menghitung beban penyusutan yang telah habis masa manfaatnya

\begin{tabular}{|c|c|c|c|c|c|c|c|}
\hline & ngan Aktiva Tet & T.Kala & $\begin{array}{r}\mathrm{Pu} \\
\mathrm{Pe}\end{array}$ & $\begin{array}{l}\text { a Menurut Un } \\
31 \text { Desember }\end{array}$ & $\begin{array}{l}\text { lang-Unda } \\
015\end{array}$ & Perpajakan $\mathrm{N}$ & 36 Tahun 2008 \\
\hline NO & AKTIVA & $\begin{array}{r}\text { TAH } \\
\text { PEROL }\end{array}$ & $\begin{array}{l}\text { N } \\
\text { HAN }\end{array}$ & $\begin{array}{c}\text { HARGA } \\
\text { PEROLEHAN }\end{array}$ & $\begin{array}{c}\text { MASA } \\
\text { MANFAAT }\end{array}$ & $\begin{array}{c}\text { TARIF } \\
\text { PENYUSUTAN }\end{array}$ & PENYUSUTAN \\
\hline 1 & Lemari Arsip & January & 2010 & 10.500 .000 & 4 & $25 \%$ & 2.625 .000 \\
\hline 2 & Kursi + Meja Kerja & January & 2010 & 9.500 .000 & 4 & $25 \%$ & 2.375 .000 \\
\hline 3 & Laptop Toshiba L 510 & February & 2010 & 16.000 .000 & 4 & $25 \%$ & 4.000 .000 \\
\hline 4 & $\begin{array}{l}\text { Komputer + Printer \& } \\
\text { Scan Canon }\end{array}$ & Maret & 2012 & 8.000 .000 & 4 & $25 \%$ & 2.000 .000 \\
\hline & & & TO & $\mathrm{TAL}$ & & & 11.000 .000 \\
\hline
\end{tabular}

\section{Sumber : Data yang diolah}

Berdasarkan Tabel 4.5 Biaya penyusutan ini merupakan pengelompokkan aktiva tetap yang termasuk dalam kelompok I dan besar beban penyusutan I Sebesar Rp. 11.000.000 Sesuai dengan Undang-undang No.7 Tahun 1983 yang diubah terakhir kali dengan Undang-Undang No.36 Tahun 2008 Pasal 11 mengenai pajak penghasilan dengan itu penulis melakukan perhitungan penyusutan aktiva tetap menurut undang- undang perpajakan dengan melakukan pengelompokkan aktiva tetap ke dalam kelompok-kelompok aktiva sesuai dengan undang-undang perpajakan No.36 tahun 2008 tentang pajak penghasilan serta Pengelompokkan aktiva tetap yang berlandasan pada peraturan Menteri Keuangan Republik Indonesia Nomor 96/PMK.03/2009 . Adapun perhitungan dan pengelompokkannya adalah sebagai berikut : 
Perhitungan Aktiva Tetap PT.Kalanafat Putra Menurut Undang-Undang Perpajakan No.36 Tahun 2008 Per 31 Desember 2015

\begin{tabular}{|c|c|c|c|c|c|c|c|}
\hline $\mathrm{NO}$ & Aktiva & Tahun Per & lehan & $\begin{array}{c}\text { Harga } \\
\text { Perolehan }\end{array}$ & $\begin{array}{c}\text { Masa } \\
\text { Manfaat }\end{array}$ & $\begin{array}{c}\text { Tarif } \\
\text { Penyusutan }\end{array}$ & Penyusutan \\
\hline 1 & $\begin{array}{l}\text { Dump Truck Dyna T } \\
130 \mathrm{HT}\end{array}$ & Februari & 2008 & 226.100 .000 & 8 & $12,50 \%$ & 28.262 .500 \\
\hline 2 & $\begin{array}{l}\text { Dump Truck Dyna } \\
\text { T130 HT }\end{array}$ & Oktober & 2008 & 474.200 .000 & 8 & $12,50 \%$ & 59.275 .000 \\
\hline 3 & $\begin{array}{l}\text { Excavator Caterpilar } \\
\text { 320D }\end{array}$ & Agustus & 2008 & 1.028 .272 .000 & 8 & $12,50 \%$ & 128.534 .000 \\
\hline 4 & $\begin{array}{l}\text { Caterpilar Vibratory } \\
\text { C5533E }\end{array}$ & Oktober & 2008 & 771.616 .000 & 8 & $12,50 \%$ & 96.452 .000 \\
\hline 5 & $\begin{array}{l}\text { Excavator Caterpilar } \\
\text { 320D }\end{array}$ & Desember & 2008 & 1.223.106.745 & 8 & $12,50 \%$ & 152.888 .343 \\
\hline 6 & $\begin{array}{l}\text { Dump Truck Dutro } 130 \\
\text { HD }\end{array}$ & Januari & 2009 & 249.500 .000 & 8 & $12,50 \%$ & 31.187 .500 \\
\hline 7 & $\begin{array}{l}\text { Excavator Komatsu PC } \\
200\end{array}$ & Agustus & 2009 & 1.102 .222 .000 & 8 & $12,50 \%$ & 137.777 .750 \\
\hline 8 & $\begin{array}{l}\text { Buldoser K D85E-SS- } \\
2 \mathrm{~A} / \mathrm{S} 1\end{array}$ & Agustus & 2009 & 1.903 .838 .000 & 8 & $12,50 \%$ & 237.979 .750 \\
\hline 9 & $\begin{array}{l}\text { Excavator Komatsu PC } \\
200\end{array}$ & Desember & 2009 & 800.000 .000 & 8 & $12,50 \%$ & 100.000 .000 \\
\hline 10 & $\begin{array}{l}\text { Dump Truck Nissan } 10 \\
\text { Roda }\end{array}$ & Desember & 2009 & 850.000 .000 & 8 & $12,50 \%$ & 106.250 .000 \\
\hline 11 & $\begin{array}{l}\text { Dump Truck Hino } 10 \\
\text { Roda }\end{array}$ & Desember & 2009 & 890.000 .000 & 8 & $12,50 \%$ & 111.250 .000 \\
\hline 12 & $\begin{array}{l}\text { Dump T } 10 \text { R FM } 260 \\
\text { JD }\end{array}$ & Juni & 2010 & 890.000 .000 & 8 & $12,50 \%$ & 111.250 .000 \\
\hline 13 & Air Conditioner (AC) & Januari & 2011 & 9.000 .000 & 8 & $12,50 \%$ & 1.125 .000 \\
\hline 14 & Mesin Foto Copy & Januari & 2012 & 28.000 .000 & 8 & $12,50 \%$ & 3.500 .000 \\
\hline 15 & Alled Towing Winch & Oktober & 2013 & 275.000 .000 & 8 & $12,50 \%$ & 34.375 .000 \\
\hline 16 & Air Conditioner (AC) & Januari & 2014 & 19.000 .000 & 8 & $12,50 \%$ & 2.375 .000 \\
\hline 17 & $\begin{array}{l}\text { Excavator PC 200- } \\
8 / \mathrm{C} 13015\end{array}$ & April & 2014 & 1.436 .400 .000 & 8 & $12,50 \%$ & 179.550 .000 \\
\hline 18 & $\begin{array}{l}\text { Buldozer D85E-SS- } \\
\text { 2/J16837 }\end{array}$ & Agustus & 2014 & 2.552 .805 .000 & 8 & $12,50 \%$ & 319.100 .625 \\
\hline 19 & $\begin{array}{l}\text { Excavator Caterpilar } \\
\text { 320D }\end{array}$ & November & 2014 & 1.400 .000 .000 & 8 & $12,50 \%$ & 175.000 .000 \\
\hline 20 & $\begin{array}{l}\text { Excavator Caterpilar } \\
\text { 320D }\end{array}$ & November & 2014 & 1.400 .000 .000 & 8 & $12,50 \%$ & 175.000 .000 \\
\hline 21 & $\begin{array}{l}\text { Excavator Caterpilar } \\
\text { 320D }\end{array}$ & November & 2014 & 1.400 .000 .000 & 8 & $12,50 \%$ & 175.000 .000 \\
\hline 22 & $\begin{array}{l}\text { Ultratrex H U AT200 } \\
\text { ER }\end{array}$ & Desember & 2014 & 2.860 .000 .000 & 8 & $12,50 \%$ & 357.500 .000 \\
\hline \multicolumn{7}{|c|}{ TOTAL } & 2.723.632.468 \\
\hline
\end{tabular}

\section{Sumber : Data Olah}

Berdasarkan table 4.6 beban penyusutan ini merupakan pengelompokkan aktiva tetap yang termasuk dalam kelompok II dan besar biaya penyusutan kelompok II sebesar Rp.
2.723.632.468.- yang termasuk dalam kelompok II merupakan asset-aset yang masa manfaat/umur ekonomisnya 8 Tahun atau 
dibawah 8 Tahun dan perhitungan penyusutan

ini menggunakan metode garis lurus.

Tabel 4.7

Perhitungan Aktiva tetap Kelompok IV

Perhitungan Aktiva Tetap PT.Kalanafat Putra Menurut Undang-Undang Perpajakan No.36

Tahun 2008 Per 31 Desember 2015

\begin{tabular}{|c|c|c|c|c|c|c|c|}
\hline No & Aktiva & \multicolumn{2}{|c|}{$\begin{array}{c}\text { Tahun } \\
\text { Perolehan }\end{array}$} & $\begin{array}{c}\text { Harga } \\
\text { Perolehan } \\
\text { (Rp) }\end{array}$ & $\begin{array}{c}\text { Masa } \\
\text { Manfaat }\end{array}$ & $\begin{array}{c}\text { Tarif } \\
\text { Penyusutan }\end{array}$ & $\begin{array}{l}\text { Penyusutan } \\
\text { (Rp) }\end{array}$ \\
\hline \multicolumn{8}{|c|}{ Bangunan } \\
\hline 1 & $\begin{array}{l}\text { Bangunan } \\
\text { Non } \\
\text { Permanen }\end{array}$ & Januari & 2014 & 452.000 .000 & 10 & $10 \%$ & 45.200 .000 \\
\hline
\end{tabular}

Sumber : Data Olahan.

Berdasarkan table 4.7 Beban penyusutan ini merupakan pengelompokkan Aktiva Tetap yang termasuk dalam kelompok IV dan besar biaya penyusutan kelompok IV Sebesar Rp. 45.200.000.- yang termasuk dalam kelompok IV merupakan Aset Bangunan.

Perbandingan Aktiva Tetap Pernyataan standard akuntansi keuangan (PSAK) dan Undangundang Perpajakan

Perlakuan akuntansi terhadap koreksi fiskal atas berbagai perbedaan secara komersial dengan secara fiskal, baik karena adanya beda tetap maupun beda waktu. Terjadi adanya koreksi karena hasil dari perhitungan kedua metode menurut komersial dan fiscal berbeda jadi perlu adanya koreksi Negatif atau positif adapun penjelasan tentang Koreksi negatif dan positif sebagai berikut :

a. Koreksi Negatif

Koreksi negatif adalah koreksi fiskal yang mengakibatkan adanya penambahan biaya yang telah diakui dalam laporan labarugi secara komersial menjadi semakin kecil apabila dilihat secara fiscal, atau yang akan mengakibatkan adanya pengurangan penghasilan kena pajak.

b. Koreksi Positif.

Koreksi positif adalah koreksi yang mengakibatkan adanya pengurangan biaya yang telah diakui dalam laporan laba rugi secara komersial menjadi semakin kecil apabila dilihat secara fiscal, atau yang akan mengakibatkan adanya penambahan penghasilan kena pajak.

Dari hasil penelitian tersebut penulis memaparkan perbandingan dari hasil perhitungan kedua metode penyusutan untuk membandingkan adanya koreksi fiskal. Adapun perbandingannya sebagai berikut :

Tabel 4.8

Perbandingan Aktiva Tetap PSAK dan Undang-undang Perpajakan

\begin{tabular}{|c|c|c|c|}
\hline \multicolumn{4}{|c|}{ Perbandingan Penyusutan Aktiva Tetap PSAK dan Undang-undang Perpajakan } \\
\hline Keterangan & Komersial & Koreksi & Fiskal \\
\hline Penyusutan & $\mathrm{Rp} \quad 3.065 .183 .754$ & $+\mathrm{Rp} \quad 285.351 .286$ & Rp $\quad 2.779 .832 .468$ \\
\hline
\end{tabular}

Komersial :

Akm beban Penyusutan $\quad 3.065 .183 .754$ 
Beban Penyusutan

3.065 .183 .754

Fiskal :
Akm Beban Penyusutan
2.779.835.468
Beban Penyusutan
2.779.835.468

Tabel 4.8 merupakan hasil dari perhitungan Aktiva tetap menurut PSAK dan Undang-undang perpajakan nilai tersebut diambil atas uraian perhitungan Peraturan Standar akuntansi keuangan sebesar Rp 3.065.183.754 dan menurut Undang-undang perpajakan pada kelompok I dengan masa manfaat 4 tahun sebesar Rp 11.000.000.-, Kelompok II dengan masa manfaat 8 tahun sebesar Rp 2.723.632468.- dan kelompok IV dengan masa manfaat 10 tahun sebesar 45.200.000 jadi total perhitungan beban penyusutan Menurut Undang-undang perpajakan adalah $\mathrm{Rp} 2.779 .832 .468$ sehingga jumlah selisih yang terjadi antara perhitungan penyusutan kedua metode tersebut adalah $\mathrm{Rp}$ 285.351.286.-

Dari hasil analisis tersebut terlihat lebih kecilnya Perhitungan Metode Penyusutan Aktiva tetap menurut Undang-undang Perpajakan Nomor 36 Tahun 2008 Tentang pajak penghasilan dan peraturan menteri keuangan republic Indonesia No 96/PMK.03/2009 dibandingkan dengan Penyusutan Menurut Pernyataan standar akuntansi keuangan (PSAK) selisih inilah yang disebut dengan Koreksi Fiskal Positif sebesar Rp 285.351.286.- karena mengakibatkan pengurangan biaya yang telah di akui dalam laporan laba rugi secara fiskal sehingga akan berpengaruh pada laporan laba rugi serta menambah penghasilan kena Pajak dan mengurangi akumulasi penyusutan aktiva tetap pada laporan neraca. Dengan adanya koreksi fiskal Positif inilah penulis dapat mengetahui perbedaan perhitungan biaya penyusutan tersebut akibat adanya beda waktu.

Perbedaan perhitungan biaya penyusutan menurut peraturan standar akuntansi keuangan dan undang-undang perpajakan sejumlah Rp. 285.351.286.- yang merupakan perbedaan waktu. Perbedaan waktu tersebut dikarenakan adanya perbedaan dalam menghitung biaya penyusutan dari kedua konsep perhitungan beban penyusutan, perbedaan-perbedaan tersebut antara lain :

1. Dalam pernyataan Standar Akuntansi Keuangan aktiva tetap tidak di kelompokkan dan untuk umur ekonomis tiap jenis aktiva tetap tidak ditentukan sedangkan didalam undang-undang perpajakan aktiva tetap dikelompokkan menjadi dua yaitu kelompok aktiva tetap bukan bangunan dan bangunan. Pengelompokkan aktiva tetap bukan bangunan juga dibagi menjadi 4 kelompok berdasarkan umur ekonomisnya dan untuk kelompok bangunan dibagi menjadi dua kelompok yaitu kelompokkan bangunan permanen dan non permanen.

2. Dalam menghitung biaya penyusutan menurut pernyataan standar akuntansi keuangan tidak adanya tarif untuk menghitung jumlah biaya penyusutan sedangkan menurut undang-undang perpajakan ditetapkan tarif untuk menghitung jumlah biaya penyusutannya.

3. Dalam pernyataan standar akuntansi keuangan menyarankan masa manfaat suatu aktiva ditentukan berdasarkan pengalaman terhadap jenis aktiva tersebut sedangkan menurut undang-undang perpajakan sudah ditentukan di dalam undang-undang.

4. Perbedaan-perbedaan diatas disebut juga dengan beda waktu karena pada akhirnya nilai beban penyusutan diakhir masa manfaat asset pada Pernyataan Standar Akuntansi (PSAK) dan UU Perpajakan akan sama dengan Nol atau Nihil. 


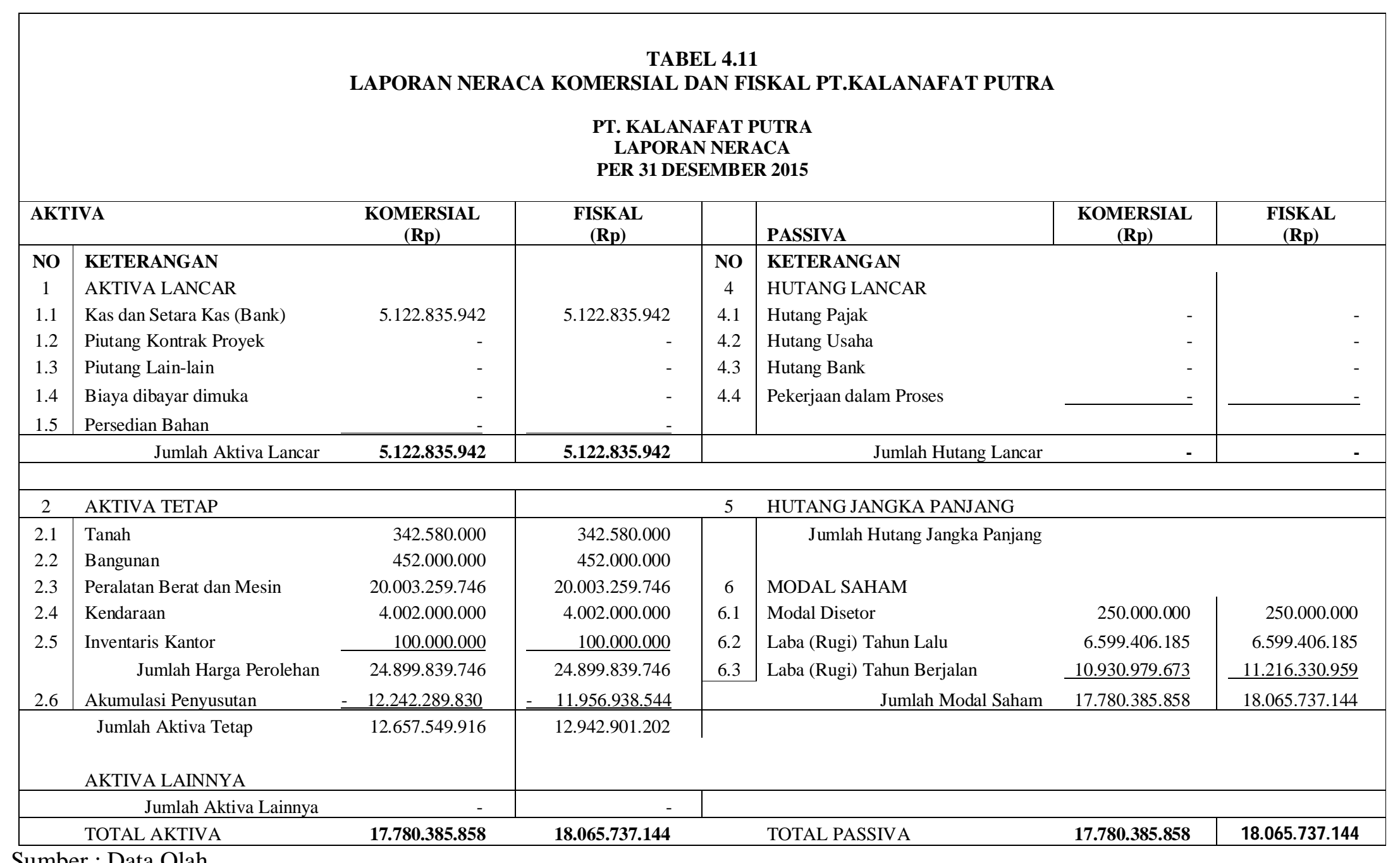


Tabel 4.12

Laporan Laba/(Rugi) Komersial Dan Fiskal PT.Kalanafat Putra.

\begin{tabular}{|c|c|c|}
\hline \multicolumn{3}{|c|}{ PT.KALANAFAT PUTRA LAPORAN LABA/(RUGI) PER 31 DESEMBER 2015} \\
\hline \multirow[b]{2}{*}{ KETERANGAN } & KONSTRUKSI & KONSTRUKSI \\
\hline & $\begin{array}{c}\text { KOMERSIAL } \\
(\text { Rp) }\end{array}$ & $\begin{array}{c}\text { FISKAL } \\
(\mathbf{R p}) \\
\end{array}$ \\
\hline \multicolumn{3}{|l|}{ I. PENDAPATAN } \\
\hline -Pendapatan Pekerjaan Proyek & 99.328 .287 .273 & 99.328 .287 .273 \\
\hline Jumlah Pendapatan & 99.328 .287 .273 & 99.328 .287 .273 \\
\hline \multicolumn{3}{|l|}{ II. HARGA POKOK PENJUALAN } \\
\hline \multicolumn{3}{|l|}{ Biaya Pelaksanaan Proyek } \\
\hline -Bahan Baku/ Material & 70.569 .868 .000 & 70.569 .868 .000 \\
\hline - Biaya Operasional Alat, Spart Part, BBM \& Oil & 7.340 .361 .000 & 7.340 .361 .000 \\
\hline - Mobilisasi \& Demobilisasi Kendaraan \& Alat Berat & 1.142 .575 .000 & 1.142 .575 .000 \\
\hline - Upah Langsung & 3.081 .650 .000 & 3.081 .650 .000 \\
\hline Jumlah Harga Pokok Penjualan & 82.134 .454 .000 & 82.134 .454 .000 \\
\hline III. LABA KOTOR USAHA & 17.193 .833 .273 & 17.193 .833 .273 \\
\hline \multicolumn{3}{|l|}{ IV. BIAYA USAHA LAINNYA (UMUM \& ADMINISTRASI) } \\
\hline - Gaji Karyawan & 922.750 .000 & 922.750 .000 \\
\hline - Transport Lokal & 67.225 .000 & 67.225 .000 \\
\hline - Biaya Penyusutan & 3.065 .183 .754 & 2.779 .832 .468 \\
\hline Sub Jumlah & 4.055.158.754 & 3.769 .807 .468 \\
\hline - Biaya ATK & 27.371 .500 & 27.371 .500 \\
\hline - Telepon/ HP, Koran, Listrik, dan Air & 69.420 .000 & 69.420 .000 \\
\hline - Perlengkapan Kantor & 19.000 .000 & 19.000 .000 \\
\hline - Biaya Dokumen Lelah/ Kontrak dan Pelaporan & 25.115 .000 & 25.115 .000 \\
\hline - Reparasi \& Pemeliharaab Kendaraan dan Peralatan & 297.603 .000 & 297.603 .000 \\
\hline - Perjalanan Dinas \& Akomodasi & 120.840 .000 & 120.840 .000 \\
\hline - Perpanjangan \& Kelengkapan Surat Perusahaan & 81.500 .000 & 81.500 .000 \\
\hline - Asuransi Jaminan Proyek & 1.291 .566 .000 & 1.291 .566 .000 \\
\hline - Asuransi Tenaga Kerja & 108.248 .000 & 108.248 .000 \\
\hline - Asuransi Administrasi Bank & 2.831 .346 & 2.831 .346 \\
\hline - Biaya Lain-lain & 164.200 .000 & 164.200 .000 \\
\hline Sub Jumlah & 2.207 .694 .846 & 2.207 .694 .846 \\
\hline Jumlah Biaya Usaha Lainnya (Umum \& Administrasi) & 6.262 .853 .600 & 5.977 .502 .314 \\
\hline V. LABA / (RUGI) SEBELUM PAJAK & 10.930 .979 .673 & 11.216.330.959 \\
\hline
\end{tabular}

Sumber : Data olahan

Berdasarkan tabel 4.12 inilah kita dapat lihat penyajian dari perbandingan Laporan Laba Rugi menurut komersil dan fiscal

\section{KESIMPULAN}

1. Dari segi penyajian Laporan keuangan PT.Kalanafat Putra pada nilai Beban Penyusutan dan Akumulasi Depresiasi Beban Penyusutannya terjadi salah perhitungan yang disebabkan karena Aset yang telah habis masa manfaatnya tapi dari pihak perusahaan masih menghitung beban penyusutannya. Dapat dilihat pada tabel 4.3 Beban penyusutannya senilai Rp. 3.206.171.849 dan pada tabel 4.4 senilai Rp. 3.065.183.754 sehingga terjadi selisih 140.988 .095

2. Dari penyajian Daftar Aktiva yang penulis teliti Perusahaan tidak mencantumkan nilai sisa sehingga pada perhitungan beban penyusutan nilai sisa Rp. 0,- dari nilai sisa 
atau residu ini nilai beban penyusutan peraset terlihat besar.

3. Perhitungan beban penyusutan Aktiva Tetap menurut Pernyataan Standar Akuntansi Keuangan beban penyusutan tersebut sebesar Rp. 3.065.183.754,- sedangkan menurut Undang-Undang Perpajakan sebesar Rp. 2.779.832.468,- sehingga dari kedua Konsep perhitungan Beban Penyusutan tersebut menimbulkan perbedaan sebesar Rp. 285.351.286.Perbedaan tersebut inilah penulis membuat perbandingan Beban Penyusutan. Laporan Keuangan PT.Kalanafat Putra dengan adanya Perbedaan metode penyusutan Aktiva tetap akibat adanya beda waktu yang disebabkan adanya perbedaan beban penyusutan antara Laporan Keuangan Komersial dan Laporan Keuangan Fiskal menyebabkan besarnya Penghasilan Kena Pajak untuk Tahun Berjalan berbeda dimana menurut Komersial Perusahaan memiliki PKP sebesar Rp. 10.930.979.673,Sedangkan fiskal melaporkan bahwa perusahaan memilik PKP sebesar Rp 11.216.330.959,-

\section{SARAN.}

Berdasarkan Hasil pembahasan dan analisis yang dilakukan, maka Penulis memberikan saran kepada Perusahaan PT.Kalanafat Putra sebagai berikut :

1. Bahwa dalam menghitung Beban Penyusutan pihak Accounting PT.Kalanafat Putra perlu lebih teliti dalam Perhitungannya karena terjadi kesalahan dalam perhitungannya yang seharusnya beban penyusutan masa manfaatnya telah habis tapi perusahaan masih menghitung bebannya serta Perusahaan dalam menentukan masa manfaat Aktiva Tetap

\section{DAFTAR PUSTAKA}

Arief sugiono, S.E dan Yanuar Nanok Soenarno , S.E., M.Ak "Akuntansi dan pelaporan keuangan Grasindo, Jakarta

Duwi Priyatno, Laporan keuangan $\mathrm{MyOb} \&$ Peachtree, Best Publisher Yogyakarta
Perusahaan berdasarkan Pernyataan Standar Akuntansi Keuangan jangan hanya berdasarkan pengalaman saja perlu juga pertimbangan-pertimbangan lain dalam menentukan masa manfaatnya seperti faktor pemakaian, perubahan teknologi serta frekuensi penggunaan Aktiva sehingga kerugian yang diakibatkan penetapan masa manfaat yang tidak tepat dapat dihindari.

2. Penulis menyarankan agar perusahaan menentukan Nilai sisa dari tiap Aktiva Tetap yang di miliki Perusahaan PT.Kalanafat Putra agar ketika suatu asset habis masa manfaatnya, asset tetap tersebut masih memiliki nilai residu atau nilai sisa sehingga kurang relevan jika asset tetap yang telah habis masa manfaatnya namun masih dapat digunakan dalam mendukung kegiatan operasional Perusahaan dengan nilai residunya diakui sebesar nol, untuk itu perusahaan alangkah baik untuk menetukan nilai residu atau nilai sisa dari tiap Aktiva Tetap Perusahaan PT.Kalanafat Putra.

3. Sebaiknya Perusahaan menghitung dan melaporkan Laporan Keuangan Komersial Perusahaan PT.Kalanafat Putra dilakukan berdasarkan Peraturan-Peraturan yang ada untuk mempermudah Perusahaan menghitung Pajak Tahun Berjalan. Perusahaan disarankan untuk benar-benar memperhatikan aturan-aturan dalam menghitung beban penyusutan Aktiva tetap yang dimiliki oleh Perusahaan, karena dari kedua konsep perhitungan biaya penyusutan tersebut baik menurut pernyataan Standar Akuntansi Keuangan No.16 dan UndangUndang Perpajakan No.36 Tahun 2008 pasal 11 terdapat persamaan dan perbedaan, pengetahuan yang mendalam terhadap aturaaturan ini akan menghindari terdapat kesalahan-kesalahan yang akan merugikan bagi perusahaan PT.Kalanafat Putra.

Drs. Al.Haryono Jusup, M.B.A., Ak. "Dasardasar akuntansi" jilid II edisi 7, STIE YKPN ; Yogyakarta

Mahmud, M, Hanafi (2003) "Analisis laporan keuangan” Yogyakarta, UPP AMP YKPN. 
Prof. Dr Slamet Sugiri, M.B.A., Akt. \& Drs. Sumiyani, Akt, (2005), "Akuntansi keuangan menengah", Buku 1 Edisi revisian, Jogjakarta : UPP AMP YKPN

Prof, Dr. Zaki Baridwan, M, Sc., Akuntan, "Intermediate Accounting", Edisi 8, BPFE-Yogyakarta, 2004

Rudianto, (2012), Pengantar Akuntansi konsep \& teknik penyusunan laporan keuangan, Jakarta : Erlangga.

Soemarso.S.R,"Akuntansi Suatu Pengantar", Rineka Cipta, Jakarta, 1999
S. Munawir “Pajak Penghasilan” Edisi Pertama, BPFE, Yogyakarta

Syaiful Bahri, S.E., MSA "Pengantar akuntansi berdasarkan SAK ETAP dan IFRS" Edisi Penerbit : Andi Yogyakarta.

S.Warren, James M, Reeve, dan Philip E, Fess (2008) "Pengantar akuntansi" edisi 21 Salemba empat, jakarta

Wibowo S.E., M.M., Ak dan AbuBakar Arif, S.E., M.M "Akuntansi keuangan dasar I" edisi ke tiga, Penerbit : Cikal sakti, Jakarta 